\title{
Evaluasi Pemberian dan Penggunaan Obat Antihipertensi pada Pasien Lansia di Puskesmas Sukarami Palembang
}

\author{
Ainun Wulandari", Vira Ardhianingsih \\ Program Studi Farmasi, Fakultas Farmasi, Institut Sains dan Teknologi Nasional, Jakarta \\ Email: ainun_wulandari@istn.ac.id; viraardhina2@gmail.com \\ Korespondensi: \\ Ainun Wulandari \\ Program Studi Farmasi, Fakultas Farmasi, Institut Sains dan Teknologi Nasional, Jakarta \\ ainun_wulandari@istn.ac.id
}

\begin{abstract}
Abstrak
Hipertensi atau tekanan darah tinggi adalah peningkatan tekanan darah sistolik lebih dari $140 \mathrm{mmHg}$ dan tekanan darah diastolik lebih dari $90 \mathrm{mmHg}$ pada dua kali pengukuran dengan selang waktu lima menit dalam keadaan cukup istirahat/tenang. Hipertensi masih menjadi salah satu penyakit yang prevalensinya mengalami peningkatan. Tujuan dari penelitian ini adalah untuk mengetahui profil pengobatan dan kesesuaian pemberian obat antihipertensi pada pasien lansia di Puskesmas Sukarami Palembang tahun 2020. Penelitian ini merupakan penelitian non eksperimental dengan metode deskriptif dan pengambilan data secara retrospektif. Data diambil dari rekam medis pasien di Puskesmas Sukarami Palembang tahun 2020. Hasil penelitian menggunakan 72 sampel, didapatkan hasil bahwa kebanyakan pasien dalam penelitian ini, berjenis kelamin laki-laki $(54,17 \%)$, usia kisaran 60-74 tahun (91,67\%), dengan terbanyak hipertensi stage II $(65,28 \%)$ serta penyakit penyerta terbanyak yaitu diabetes mellitus (15,28\%). Golongan obat antihipertensi terbanyak yaitu CCB dengan obat terbanyak amlodipin $(94,44 \%)$. Pola terapi paling banyak yaitu monoterapi golongan CCB amlodipin (94,44\%), penggunaan politerapi dua obat dengan kombinasi terbanyak yaitu golongan CCB dan ACEI (4,17\%). Kesesuaian pemilihan obat antihipertensi seluruh pasien dikatakan sesuai dengan JNC 8 $(100 \%)$ dan kesesuaian pemilihan dosis obat antihipertensi dengan JNC 8 sebanyak 69 pasien $(95,83 \%)$ dan dosis terlalu tinggi sebanyak 3 pasien $(4,17 \%)$.
\end{abstract}

Kata Kunci: hipertensi; JNC 8; lansia; penggunaan obat; Puskesmas

INPHARNMED Journal, Vol.5, No.2, Tahun 2021, 1-7

Available from: http://ejournal.almaata.ac.id/index.php/INPHARNMED 


\title{
EVALUATION OF ADMINISTRATION AND USE OF ANTIHYPERTENSIVE DRIGS IN ELDERLY PATIENTS AT PRIMARY HEALTH CARE IN SUKARAMI, PALEMBANG
}

\begin{abstract}
Hypertension or high blood pressure is an increase in systolic blood pressure of more than $140 \mathrm{mmHg}$ and diastolic blood pressure of more than $90 \mathrm{mmHg}$ on two measurements with an interval of five minutes in a state of rest/calm. Hypertension is still a disease whose prevalence is increasing. The purpose of this study was to knowing the treatment profile and the suitability of giving antihypertensive drugs to elderly patients at primary health care in Sukarami, Palembang in 2020. This research is a non experimental research with descriptive method and retrospective data collection. The data is taken from the medical records of patients at primary health care in Sukarami, Palembang in 2020. The results of the study used 72 samples, it was found that most patients in this study were male $(54,17 \%)$, age range $60-74$ years $(91,67 \%)$, with the highest stage II hypertension $(65,28 \%)$ and the most comorbidities, namely diabetes mellitus $(15,28 \%)$. The most antihypertensive drug class was CCB with the most drug being amlodipine (94,44\%). The pattern of therapy at most was monotherapy with the most drug, namely amlodipine (94,44\%), the use polytherapy with 2 drugs with the highest combination of CCB and ACEI $(4,17 \%)$. The suitability of the selection of appropriate antihypertensive drugs for all patients was said to be appropriate with JNC 8 (100\%) and the suitability of dose selection antihypertensive drugs with the appropriate dose category with JNC 8 as much as 69 patients $(95,83 \%)$ and doses to hig as much as 3 patients (4,17\%).
\end{abstract}

Keyword: hypertension, elderly, drug use, JNC 8, primary health care

Received: 28 September 2021

Accepted: 13 Desember 2021

\section{PENDAHULUAN}

Hipertensi merupakan salah satu penyakit kardiovaskular, yaitu peningkatan tekanan darah diatas batas normal $\geq 140 / 90 \mathrm{mmHg}$. Hipertensi dikenal sebagai "sillent killer" karena biasanya tidak memiliki tanda atau gejala dan banyak orang yang tidak tahu bahwa mereka mengidapnya. Sekitar 77,9 juta orang dewasa Amerika ( 1 dari 3 orang) dan sekitar 970 juta orang di seluruh dunia memiliki tekanan darah yang tinggi. Hipertensi dapat menyebabkan resiko morbiditas atau mortalitas dini, yang akan terjadi saat kondisi tekanan sistolik dan diastolik meningkat. Peningkatan tekanan darah dalam jangka waktu yang panjang dapat merusak pembuluh darah di organ (jantung, ginjal, otak, dan mata) ${ }^{1}$.

Hipertensi merupakan penyebab kematian nomor 3 setelah stroke dan tuberkulosis, yakni mencapai 6,7\% dari populasi kematian pada semua umur di Indonesia. 
Hasil Riset Kesehatan Dasar tahun 2018 menunjukkan, di Indonesia sekitar 34,1\% penduduknya mengalami hipertensi dengan perbandingan 31,3\% pria dan 36,9\% wanita ${ }^{2}$. Kota Palembang menyumbang angka tertinggi sekaligus menduduki urutan ketiga dari sepuluh penyakit terbanyak 2018 sebesar 1.130 .254 penderita hipertensi ${ }^{3}$. Angka kejadian hipertensi pada lansia di Indonesia menurut data Riset Kesehatan Dasar tahun 2018 menunjukkan angka yang cukup tinggi yaitu 45,3-69,5\% ${ }^{2}$. Menurut data pasien hipertensi di Puskesmas Sukarami Palembang menunjukkan peningkatan dari tahun 20182019 yaitu 45,43\%-79,1\% tetapi mengalami penurunan di tahun 2020 yaitu 65,4\% karena adanya pandemi. Walaupun mengalami penurunan tetapi penyakit hipertensi di Puskesmas Sukarami Palembang masih menduduki urutan pertama penyakit tertinggi dari tahun 2018-2020.

Menurut Pharmaceutical Care Network Europe 2017 ketidaksesuaian penggunaan obat adalah peristiwa atau keadaan yang melibatkan terapi obat yang benarbenar atau berpotensi mengganggu hasil kesehatan yang diinginkan. Kejadian dikatakan sesuai atau tidak sesuai jika memenuhi komponen-komponen penyebabnya. Jika komponen penyebab itu terjadi dan hasilnya tinggi, maka akan berdampak pada pasien yaitu efek samping dan tidak tercapainya efek terapi yang diinginkan. Pengobatan pada pasien hipertensi merupakan pengobatan jangka panjang, bahkan pengobatan seumur hidup 4 . Pada hasil penelitian yang dilakukan di Surakarta diketahui bahwa dari 350 pasien yang terdiagnosa hipertensi lebih banyak dialami oleh pasien usia geriatri yang baru akan memasuki usia geriatri yaitu usia 66-74 tahun sebesar 50,9\%. Penggunaan obat antihipertensi sebagai terapi pada pasien lanjut usia yang tepat dapat mengurangi morbiditas dan mortalitas pengobatan yang sesuai bagi pasien usia geriatri. Secara umum, pemberian obat dapat dinyatakan rasional bila telah memenuhi kriteria tepat pasien, tepat indikasi, tepat obat dan tepat dosis ${ }^{5}$. Geriatri lebih dominan beresiko terkena penyakit kardiovaskular absolut lebih tinggi, karena adanya keterikatan antara bertambahnya usia terhadap tekanan darah tinggi ${ }^{6}$.

Berdasarkan kejadian tersebut maka penelitian ini sangat penting dilakukan untuk mengevaluasi kesesuaian pemberian obat hipertensi pada pasien lansia di Puskesmas Sukarami, Palembang berdasarkan standar terapi utama menurut Hypertension: The Silent Killer: Updated Joint National Committee (JNC)-8 Guideline 
Recommendations. Hasil penelitian ini diharapkan dapat digunakan sebagai dokumentasi dan bahan evaluasi terhadap pelayanan kesehatan untuk meningkatkan mutu pelayanan baik oleh dokter maupun farmasis.

\section{METODE PENELITIAN}

\section{Populasi dan Sampel}

Populasi pada penelitian ini adalah semua rekam medis pasien lansia dengan diagnosa hipertensi yang melakukan pengobatan di Puskesmas Sukarami Palembang periode Januari-Desember 2020. Berdasarkan data rekam medis di Puskesmas Sukarami Palembang ada 72 pasien lansia hipertensi periode Januari-Desember 2020. Pengambilan sampel dalam penelitian ini menggunakan metode Nonprobability Sampling adalah sensus/total sampling yaitu teknik pengambilan sampel yang tidak memberi peluang/kesempatan sama bagi setiap unsur atau anggota populasi untuk dipilih menjadi sampel. Teknik Total Sampling merupakan teknik pengambilan sampel di mana seluruh anggota populasi dijadikan sampel. Penelitian yang dilakukan pada populasi di bawah 100 sebaiknya dilakukan dengan sensus, sehingga seluruh anggota populasi tersebut dijadikan sampel semua sebagai subyek yang dipelajari atau sebagai responden pemberi informasi ${ }^{7}$. Sampel dari penelitian ini adalah semua populasi yang memiliki data rekam medis yang lengkap, pasien yang rutin berobat (2-4 kali melakukan pengobatan dalam 1 bulan), yaitu 72 rekam medis pasien. Data rekam medis yang lengkap yaitu mencantumkan nama, usia, jenis kelamin, diagnosa utama, penyakit penyerta, data pemeriksaan tekanan darah, dan terapi yang diberikan (nama obat, dosis, dan aturan pakai).

\section{Rancangan Penelitian}

Penelitian ini termasuk penelitian observasional deskriptif dan pengambilan data secara retrospektif, yaitu dengan mencatat data-data yang diperlukan untuk penelitian dari rekam medis pasien yang menjalani pengobatan atau rawat jalan di Puskesmas Sukarami Palembang periode Januari-Desember 2020. Penelitian ini dilakukan di Puskesmas Sukarami Palembang selama 2 bulan yaitu bulan Februari 2021 - Maret 2021. 


\section{Cara Pengolahan dan Analisis Data}

Pada penelitian ini pengolahan dan analisis data dilakukan secara deskriptif yaitu untuk menggambarkan tentang suatu keadaan secara objektif. Setelah data dikumpulkan maka data-data tersebut dianalisis kesesuaiannya berdasarkan JNC 8. Data diolah dan dihitung persentasenya kemudian disajikan dalam bentuk tabel, selanjutnya data dianalisis secara deskriptif.

\section{Karakteristik Data Pasien}

\section{HASIL DAN PEMBAHASAN}

\section{Karakteristik Pasien Berdasarkan Jenis Kelamin}

Berdasarkan data pada Tabel 1 didapatkan bahwa persentase pasien hipertensi berjenis kelamin laki-laki lebih banyak daripada pasien perempuan. Menurut Kementerian Kesehatan Republik Indonesia tahun 2013, jenis kelamin berpengaruh pada terjadinya hipertensi. Pria mempunyai risiko sekitar 2,3 kali lebih banyak mengalami peningkatan tekanan darah sistolik dibandingkan dengan perempuan, karena pria diduga memiliki gaya hidup yang cenderung meningkatkan tekanan darah. Pada laki-laki kasus hipertensi lebih mudah didapatkan karena adanya faktor risiko yang memungkinkan terjadinya hipertensi seperti merokok dan meminum alkohol diiringi dengan makanan yang tidak sehat. Akibatnya tekanan darah pun menjadi naik karena pada laki-laki lebih banyak melakukan aktivitas fisik sehingga lebih mudah kelelahan diiringi juga pola makan dan hidup yang tidak sehat menjadi faktor dari hipertensi ${ }^{8}$. Seperti pada penelitian sebelumnya didapatkan jumlah laki-laki yang menderita hipertensi sebanyak $73,1 \%$ serta didukung juga oleh penelitian lainnya di tahun 2019 prevalensi kejadian hipertensi pada laki-laki lebih tinggi sebesar 14,79\% dibandingkan dengan perempuan sebesar $12,51 \%^{9,10}$.

Tabel I. Berdasarkan Jenis Kelamin

\begin{tabular}{lll}
\hline Jenis Kelamin & Jumlah Pasien & Persentase (\%) \\
\hline Perempuan & 33 & 45,83 \\
Laki-laki & 39 & 54,17 \\
Total & 72 & 100 \\
\hline
\end{tabular}


Faktor yang menyebabkan kemungkinan laki-laki lebih banyak mengalami kejadian hipertensi karena laki-laki tidak mempunyai hormon estrogen yang terdapat pada perempuan, sehingga laki-laki tidak mempunyai perlindungan terhadap terjadinya hipertensi ${ }^{11}$. Namun, hasil ini berbeda dengan hasil penelitian dari Riset Kesehatan Dasar yang memiliki prevalensi hipertensi pada perempuan sebesar 36,9\% dibandingkan dengan laki-laki sebesar $31,3 \%^{12}$. Walaupun terdapat perbedaan pada hasil penelitian yang dilakukan, perbedaan yang terjadi tidak terlalu signifikan besarnya karena laki-laki maupun perempuan memiliki tingkat perbedaan yang tidak terlalu jauh untuk terdiagnosa penyakit hipertensi ${ }^{13}$.

\section{Karakteristik Pasien Berdasarkan Usia}

Berdasarkan hasil pada Tabel 2, kategori lanjut usia meliputi: lanjut usia (elderly) antara 60-74 tahun, lanjut usia tua (old) antara 75-90 tahun. Pengelompokkan ini bertujuan untuk mengetahui usia hipertensi pada pasien lansia yang banyak terjadi. Pada hasil penelitian ini penyakit hipertensi pada lansia paling banyak terjadi pada kelompok usia Elderly yaitu sebanyak 66 pasien atau 91,67\% dari 72 pasien, sedangkan pada kelompok usia lanjut usia tua (old) hanya sebanyak 6 pasien atau 8,33\% dari 72 pasien. Hal ini didukung dengan adanya penelitian evaluasi ketepatan pemilihan obat hipertensi pada pasien lansia yang dilakukan oleh Rahman, A. (2019) di Puskesmas Kotagede II DIY juga didapatkan hasil kelompok usia Elderly lebih banyak persentasenya sebesar $83,82 \%$ dibandingkan kelompok usia old sebesar $16,18 \%{ }^{14}$.

Tabel II. Demografi Pasien Hipertensi di Puskesmas Sukarami Palembang Tahun 2020 Berdasarkan Usia

\begin{tabular}{ccl}
\hline Usia & Jumlah Pasien & Persentase (\%) \\
\hline Elderly 60-74 & 66 & 91,67 \\
Old 75-90 & 6 & 8,33 \\
Total & 72 & 100 \\
\hline
\end{tabular}

Faktor fisiologik dapat mempengaruhi kesehatan lansia. Semakin lanjut usia seseorang, maka kemungkinan terjadinya penurunan fungsional anatomi akan semakin besar. Penurunan fungsional anatomi tersebut menyebabkan lebih mudah timbulnya penyakit pada organ tersebut ${ }^{15}$. Pada kelompok lanjut usia tua (old) 
terdapat penurunan jumlah pasien yaitu hanya sebanyak 6 pasien berusia 75-90 tahun yang melakukan pengobatan hipertensi di Puskesmas Sukarami Palembang dengan perbandingan 3 pasien laki-laki dan 3 pasien perempuan. Penurunan jumlah pasien dapat terjadi karena rendahnya rata-rata angka harapan hidup di Indonesia terutama pada Provinsi Sumatera Selatan menurut data Badan Pusat Statistik Indonesia tahun 2020 didapatkan angka harapan hidup untuk laki-laki adalah 68,00 dan untuk perempuan adalah $71,86^{16}$. Adapun faktor lainnya adalah pada tatalaksana farmakologis umumnya yang dilakukan di Puskesmas dengan merujuk pasien ke pelayanan kesehatan sekunder yaitu rumah sakit apabila pasien berusia sangat tua karena faktor usia sangat mempengaruhi peningkatan tekanan darah. Dalam menangani hipertensi perlu juga dikelola faktor risiko kardiovaskular lainnya, kerusakan organ target dan penyakit penyerta, penanganan ini umumnya dikerjakan di fasilitas pelayanan kesehatan sekunder atau tersier ${ }^{17}$.

\section{Karakteristik Pasien Berdasarkan Tingkat Hipertensi}

Dari data hasil penelitian pada Tabel 3 didapatkan bahwa sebagian pasien yang melakukan pengobatan ke Puskesmas Sukarami Palembang mengalami hipertensi stage 2 sebanyak 47 pasien $(65,28 \%)$, sedangkan pasien hipertensi stage 1 hanya sebanyak 25 pasien $(34,72 \%)$ dari total pasien lansia yang berobat sebanyak 72 pasien. Hasil penelitian ini sesuai dengan penelitian yang dilakukan di Puskesmas Siantan Hilir Pontianak didapatkan hasil terbanyak sebesar 49 pasien $(53,26 \%)$ mengalami hipertensi stage 2 kemudian untuk hipertensi stage 1 nya hanya sebesar 43 pasien $(46,74 \%)^{18}$.

Tabel III. Berdasarkan Tekanan Darah

\begin{tabular}{ccccc}
\hline $\begin{array}{c}\text { Klasifikasi } \\
\text { Tekanan Darah }\end{array}$ & $\begin{array}{c}\text { Nilai } \\
\text { TDS }\end{array}$ & $\begin{array}{c}\text { Nilai } \\
\text { TDD }\end{array}$ & $\begin{array}{c}\text { Jumlah } \\
\text { Pasien }\end{array}$ & $\begin{array}{c}\text { Persentase } \\
\text { (\%) }\end{array}$ \\
\hline Hipertensi Stage I & $140-159$ & $90-99$ & 25 & 34,72 \\
Hipertensi Stage II & $\geq 160$ & $\geq 100$ & 47 & 65,28 \\
Total & & & 72 & 100 \\
\hline
\end{tabular}

Hal yang sama juga didapatkan pada hasil penelitian di Puskesmas Gondokusuman I Yogyakarta didapatkan pasien yang mengalami hipertensi stage 2 sebanyak 30 pasien (56,6\%) sedangkan untuk hipertensi stage 1 hanya sebanyak 23 
pasien $(43,4 \%)^{19}$. Hal ini dapat terjadi mengingat pada sampel penelitian hipertensi merupakan pasien lansia. Semakin bertambahnya usia, arteri besar kehilangan kelenturannya sehingga tekanan darah meningkat karena dipaksa melewati pembuluh darah yang mengecil. Hipertensi stage 2 dalam jangka waktu lama dapat menyebabkan kerusakan kardiovaskuler. Peningkatan 20 mmHg tekanan darah sistole menyebabkan dua kali peningkatan kejadian kardiovaskuler. Oleh karena hal tersebut tujuan terapi hipertensi adalah kontrol tekanan darah ${ }^{17}$.

Tabel IV. Berdasarkan Penurunan Tekanan Darah

\begin{tabular}{ccccc}
\hline Parameter & Nilai TDS & Nilai TDD & Jumlah Pasien & Persentase (\%) \\
\hline TD Awal & $140-159$ & $90-99$ & 25 & $34,72 \%$ \\
& $\geq 160$ & $\geq 100$ & 47 & $65,28 \%$ \\
TD Akhir & $<150$ & $<90$ & 72 & $100 \%$ \\
\hline
\end{tabular}

Evaluasi tekanan darah menurut Kemenkes RI (2013), disarankan untuk melihat perubahan tekanan darah awal dan akhir saat melakukan kontrol ulang 4 kali dalam satu bulan atau satu minggu sekali sehingga untuk membandingkan tekanan darah awal dan akhir peneliti cukup mengambil waktu 1 bulan. Menurut JNC 8 target tekanan darah untuk pasien lansia adalah $<150 / 90 \mathrm{mmHg}^{8}$. Penurunan tekanan darah selama terapi terjadi pada semua pasien dimana dapat dilihat pada Tabel 4 bahwa pasien yang tekanan darah nya sudah mencapai target $<150 / 90 \mathrm{mmHg}$ sebanyak 72 pasien, dapat dikatakan $100 \%$ pasien lansia yang mengalami hipertensi di Puskesmas Sukarami Palembang tekanan darahnya terkendali.

Peningkatan angka keberhasilan hipertensi dengan tercapainya target tekanan darah tidak hanya menggunakan terapi farmakologi tetapi didampingi dengan terapi non farmakologi yaitu menerapkan gaya hidup sehat. Semua pasien dengan prehipertensi dan hipertensi harus melakukan perubahan gaya hidup. Disamping menurunkan tekanan darah pada pasien-pasien dengan hipertensi, modifikasi gaya hidup juga dapat mengurangi berlanjutnya tekanan darah ke hipertensi pada pasienpasien dengan tekanan darah prehipertensi. Modifikasi gaya hidup sehat yang dimaksud yaitu dengan menurunkan asupan natrium, melakukan diet dengan metode Dietary Approaches to Stop Hypertension (DASH), melakukan aktifitas fisik seperti olahraga aerobik, dan mengurangi merokok ${ }^{17}$. 


\section{Karakteristik Pasien Berdasarkan Penyakit Penyerta}

Berdasarkan data dari hasil penelitian pada Tabel 5 dapat dilihat bahwa diabetes mellitus adalah penyakit penyerta yang paling banyak ditemukan yaitu 11 pasien $(15,28 \%)$ kemudian diikuti dengan ISPA dan vertigo masing - masing sebanyak 6 pasien $(8,33 \%)$. Dari total 72 pasien, terdapat 47 pasien $(65,28 \%)$ dengan penyakit penyerta dan hanya 25 pasien $(34,72 \%)$ yang tidak mempunyai penyakit penyerta. Hal ini berarti pasien dengan penyakit penyerta mempunyai jumlah yang lebih banyak dibandingkan dengan pasien tanpa penyakit penyerta.

Tabel V. Demografi Pasien Hipertensi di Puskesmas Sukarami Palembang Tahun 2020 Berdasarkan Penyakit Penyerta

\begin{tabular}{|c|c|c|}
\hline Penyakit Penyerta & Jumlah Pasien & Persentase (\%) \\
\hline Tanpa Penyakit Penyerta & 25 & 34,72 \\
\hline \multicolumn{3}{|l|}{ Dengan Penyakit Penyerta } \\
\hline Diabetes Melitus & 11 & 15,28 \\
\hline ISPA & 6 & 8,33 \\
\hline Vertigo & 6 & 8,33 \\
\hline Dispepsia & 5 & 6,94 \\
\hline Dislipidemia & 3 & 4,17 \\
\hline Gastritis & 2 & 2,78 \\
\hline ISPA + Dispepsia & 3 & 4,17 \\
\hline ISPA + Gastritis & 2 & 2,78 \\
\hline ISPA + Dislipidemia & 1 & 1,39 \\
\hline ISPA + Haemoroid & 1 & 1,39 \\
\hline DM + Dispepsia & 2 & 2,78 \\
\hline DM + Dislipidemia & 1 & 1,39 \\
\hline Dislipidemia + Dispepsia & 1 & 1,39 \\
\hline Dislipidemia + Gastritis & 1 & 1,39 \\
\hline Dispepsia + Gastritis & 1 & 1,39 \\
\hline \multirow[t]{2}{*}{ Dispepsia+Vertigo+Gastritis } & 1 & 1,39 \\
\hline & 47 & 65,28 \\
\hline Total Keseluruhan & 72 & 100 \\
\hline
\end{tabular}

Hasil penelitian yang didapat sejalan dengan penelitian sebelumnya dimana penyakit penyerta terbanyak yang terjadi pada pasien hipertensi adalah diabetes mellitus sebanyak 29,41\%. Diabetes mellitus merupakan penyakit yang sering menyertai penderita hipertensi. Tingginya prevalensi diabetes pada penderita hipertensi berisiko 4-5 kali sebagai penyebab kematian jantung koroner dan stroke. Hipertensi yang bersamaan dengan DM akan meningkatkan risiko hingga 60\% terhadap morbiditas dan mortalitas kardiovaskuler. Diabetes, hipertensi dan 
dislipidemia berkaitan erat satu dengan lainnya yang merupakan faktor risiko aterosklerosis $^{14,20}$. Hal ini sejalan dengan penelitian yang dilakukan di Puskesmas Sukarami Palembang, bahwa diabetes $(15,28 \%)$ dan dislipidemia $(4,17 \%)$ merupakan penyakit penyerta yang sering terjadi pada pasien hipertensi lansia.

Penyakit penyerta terbanyak pada penelitian ini yaitu diabetes mellitus. Diabetes mellitus adalah penyakit kronis yang terjadi ketika pankreas tidak dapat memproduksi insulin dengan cukup, atau ketika tubuh tidak efektif dalam menggunakan insulin. Diabetes mellitus yang terus dibiarkan tanpa pengobatan lamalama menyebabkan kerusakan pembuluh darah pada dinding pembuluh darah. penumpukan lemak ini dapat meningkatkan resiko pembuluh darah menyempit karena tersumbat hingga akhirnya mengeras (Aterosklerosis). Kadar lipid yang tidak normal merupakan faktor risiko untuk terjadinya komplikasi ateroklerosis pada penderita hipertensi dan diabetes. Komplikasi akan semakin meningkat pada kondisi dimana diabetes dan hipertensi terjadi secara bersamaan ${ }^{20}$. Untuk pengobatan pada pasien hipertensi yang mempunyai penyakit penyerta diabetes sesuai data semua pasien mendapatkan pengobatan golongan calcium channel blockers (CCB) yaitu Amlodipin hal ini sesuai dengan pedoman dari JNC 8 dimana amlodipin merupakan agen tambahan yang paling tepat untuk mengontrol tekanan darah pada pasien diabetes ${ }^{17}$.

Penyakit penyerta terakhir yaitu penyakit gastritis sebanyak 2 pasien $(2,78 \%)$. Penyakit gastritis ialah suatu inflamasi yang mengenai daerah dinding lambung terutama pada mukosa gaster. Gastritis dapat disebabkan oleh beberapa hal seperti oleh karena infeksi H.pylori, kebiasaan makan makanan yang pedas, asam, minuman iritatif (seperti soda), serta konsumsi kopi, alkohol, stress emosional, obat - obatan seperti NSAID, dan juga dapat disebabkan oleh karena imunitas ${ }^{21}$. Hipertensi dapat diakibatkan oleh stress yang diderita individu, sebab reaksi yang muncul terhadap impuls stres adalah tekanan darahnya meningkat. Selain itu, umumnya pasien yang mengalami stres sulit tidur, sehingga akan berdampak pada tekanan darahnya yang cenderung tinggi ${ }^{22}$. Pasien hipertensi yang mengalami stress cenderung juga mengalami gastritis karena gastritis juga dapat disebabkan oleh stres. Saat stres, orang 
cenderung makan lebih sedikit sehingga merangsang produksi asam lambung dalam jumlah yang berlebihan ${ }^{23}$.

\section{Profil Pengobatan dan Kesesuaian Pemberian Obat}

\section{Penggunaan Obat Antihipertensi}

Berdasarkan data pada Tabel 6, dapat diamati bahwa obat yang paling sering digunakan atau diberikan kepada pasien lansia dalam pengobatan di Puskesmas Sukarami Palembang Tahun 2020 adalah amlodipin dengan jumlah pasien sebanyak 68 pasien (94,44\%). Hasil penelitian ini sesuai dengan penelitian yang dilakukan di Puskesmas Kotagede II Yogyakarta, dimana CCB menjadi golongan obat terbanyak (95,58\%) pada pasien hipertensi. Pada penelitian di Puskesmas Pasir Panjang juga diperoleh hasil yang sama yaitu golongan CCB menjadi golongan obat terbanyak (75\%) diikuti dengan golongan Angiotensin Converting Enzyme Inhibitors (ACEI) (22\%) ${ }^{14,24}$.

Tabel VI. Demografi Jenis Obat Antihipertensi Berdasarkan Golongan

\begin{tabular}{cccc}
\hline Golongan Obat & Jenis Obat & Jumlah Pasien & Persentase (\%) \\
\hline Calcium Channel Blocker & Amlodipin & 68 & 94,44 \\
Angiotensi Converting & Captopril & 3 & 4,17 \\
Enzyme Inhibitor & & & \\
Beta Blocker & Bisoprolol & 1 & 1,39 \\
Total & & $\mathbf{7 2}$ & $\mathbf{1 0 0}$ \\
\hline
\end{tabular}

Amlodipin termasuk ke dalam antihipertensi golongan Calcium Channel Blocker, dimana CCB menjadi golongan antihipertensi yang paling banyak digunakan dalam penelitian ini yaitu 68 pasien. Amlodipin dapat digunakan sebagai agen tunggal untuk mengontrol tekanan darah pasien. Golongan ini sangat efektif menurunkan tekanan darah, bekerja secara langsung pada pembuluh darah untuk menyebabkan relaksasi, dan seringkali menjadi terapi lini utama. Selain itu efek samping yang ditimbulkan juga tidak terlalu berpengaruh dibandingkan penggunaan obat antihipertensi lain seperti captopril yang memiliki efek samping batuk kering yang tidak disukai oleh pasien. Amlodipin hanya digunakan sekali sehari yang dapat meningkatkan kepatuhan pasien untuk mengkonsumsinya ${ }^{25}$. Menurut pedoman JNC 8 , amlodipin yang termasuk dalam CCB dihidropiridin sangat efektif pada lansia yang menderita hipertensi. 
Mekanisme kerja CCB ini yaitu memblok kalsium masuk ke dalam dinding pembuluh darah. Hal ini akan menyebabkan pengurangan tekanan pada jantung dan menurunkan tekanan darah. Amlodipin mempunyai mekanisme yang sama dengan antagonis kalsium golongan dihidropiridin lainnya yaitu dengan merelaksasi arteriol pembuluh darah. amlodipin bersifat vaskuloselektif, memiliki bioavailibilitas oral yang relatif rendah, memiliki waktu paruh yang panjang, dan absorpsi yang lambat sehingga mencegah tekanan darah turun secara mendadak ${ }^{26}$.

Captopril merupakan antihipertensi terbanyak kedua setelah amlodipin. Captopril termasuk antihipertensi golongan Angiotensin Converting Enzyme Inhibitor yang pada penelitian ini menjadi golongan kedua setelah $\mathrm{CCB}$ yaitu sebanyak 3 pasien. ACEI mencegah pembentukan angiotensin I menjadi angiotensin II dengan menghalangi enzim yang mengubah angiotensin I menjadi angiotensin II. Dengan meghambat pembentukan angiotensin II, tekanan darah akan turun ${ }^{17}$. Antihipertensi yang terakhir yaitu bisoprolol digunakan pada 1 pasien. Bisoprolol termasuk antihipertensi golongan Beta Blocker. Menurut pedoman JNC 8 Beta blocker bekerja dengan cara menghentikan pengaktifan reseptor beta di jantung. Biasanya, rangsangan reseptor ini akan menyebabkan detak jantung meningkat dan memberi tekanan pada jantung. Dengan memblokir reseptor ini, tekanan pada jantung dan tekanan darah akan berkurang. Beta blocker tidak diindikasikan sebagai pilihan pertama pengobatan hipertensi. Alasan beta blocker digunakan sebagai pilihan kedua didasarkan pada penelitian yang menunjukkan bahwa beta blocker memiliki insiden serangan jantung atau stroke yang lebih tinggi bila digunakan untuk hipertensi pada pasien tanpa indikasi khusus ${ }^{17}$. Hal ini sejalan dengan data yang didapat bahwa beta blocker dikombinasikan dengan antihipertensi golongan lainnya yaitu dengan golongan CCB amlodipin.

\section{Pola Terapi Penggunaan Obat Antihipertensi}

Dari data penelitian didapatkan hasil bahwa pasien hipertensi lebih banyak mendapatkan monoterapi sebanyak 68 pasien (94,44\%) dibandingkan dengan politerapi 2 obat yang hanya 4 pasien (5,56\%). Hasil penelitian ini sesuai dengan 
penelitian sebelumnya yang menunjukkan bahwa subyek penelitian lebih banyak mendapatkan monoterapi sebanyak 498 pasien $(89,1 \%)$ dibanding politerapi dua obat sebanyak 61 pasien $(10,9 \%)^{28}$. Penggunaan monoterapi pada penelitian ini sudah sesuai dengan pedoman JNC 8, dimana golongan CCB termasuk rekomendasi obat antihipertensi lini pertama dikarenakan golongan CCB dapat ditoleransi dengan baik pada awal pengobatan ${ }^{17,28}$.

Pasien hipertensi akan membutuhkan dua atau lebih obat antihipertensi untuk mencapai target tekanan darah, hal tersebut teramati dari hasil penelitian ini yang tersaji pada Tabel 7. Terapi farmakologis hipertensi terutama pada hipertensi stage I diawali dengan pemakaian obat tunggal karena monoterapi mampu menurunkan tekanan darah sistolik sekitar 7-13 mmHg dan diastolik sekitar 4-8 mmHg. Jika target tekanan darah tidak tercapai dalam waktu satu bulan pengobatan, maka dapat dilakukan peningkatan dosis obat awal atau penambahan golongan obat lain yang berasal dari terapi lini pertama dan kedua dengan meminimalkan efek samping interaksi obat ${ }^{27}$. Terapi kombinasi (dengan dua golongan obat yang berbeda) dapat digunakan sebagai terapi awal jika tekanan darah sistolik $\geq 160 \mathrm{mmHg}$ dan/atau tekanan darah diastolik $>100 \mathrm{mmHg}$ atau tekanan darah sistolik $>20 \mathrm{mmHg}$ diatas target dan / atau DBP $>10 \mathrm{mmHg}$ diatas target ${ }^{17}$. Terapi kombinasi dapat menurunkan tekanan darah lebih besar dengan efek samping yang minimal. Akan tetapi apabila dilihat dari data yang didapat, penggunaan monoterapi juga digunakan pada hipertensi stage II hal ini dikarenakan kemungkinan dokter mempunyai pertimbangan khusus atau melihat kondisi pasien.

Tabel VII. Demografi Pola Terapi Penggunaan Obat Antihipertensi

\begin{tabular}{|c|c|c|c|c|}
\hline No & Golongan Obat & Jenis Obat & Frekuensi & Persentase (\%) \\
\hline \multicolumn{5}{|c|}{ Tunggal (Monoterapi) } \\
\hline \multirow[t]{2}{*}{1} & $\mathrm{CCB}$ & Amlodipin & 68 & 94,44 \\
\hline & Total & & 68 & 94,44 \\
\hline \multicolumn{5}{|c|}{ Politerapi 2 obat } \\
\hline \multirow[t]{2}{*}{1} & CCB+ACEI & Amlodipi & 3 & 4,17 \\
\hline & & +Captopril & & \\
\hline \multirow[t]{3}{*}{2} & CCB+Beta & Amlodipin+ & 1 & 1,39 \\
\hline & Blocker & Bisoprolol & & \\
\hline & Total & & 4 & 5,56 \\
\hline \multicolumn{2}{|c|}{ Total Keseluruhan } & & 72 & 100 \\
\hline
\end{tabular}


Pemberian politerapi kombinasi dua obat golongan ACEI dengan CCB lebih banyak diberikan pada pasien hipertensi. ACEI dipilih karena keamanannya tidak menimbulkan efek samping metabolik pada penggunaan jangka panjang dan memiliki efek perlindungan ginjal. CCB biasanya digunakan untuk hipertensi dengan diabetes melitus $^{28,29}$.

Kombinasi yang terakhir adalah golongan CCB dan Beta Blocker yang diberikan pada 1 orang pasien (1,39\%). Kombinasi obat golongan CCB dihydropiridin yaitu amlodipin dan Beta blocker yaitu bisoprolol digunakan sebagai tambahan untuk pengaturan denyut jantung, dapat menyebabkan penurunan tekanan darah yang lebih baik dibanding monoterapi masing-masing obat tersebut. Golongan CCB bersifat mudah untuk dimetabolisme, sehingga menjadi pilihan favorit untuk manajemen awal pasien - pasien hipertensi berat dan atau dengan komplikasi metabolik. Walaupun, CCB memiliki kurva dosis-respon yang linier, terdapat kondisi yang sangat sinerfi untuk pengontrolan tekanan darah bila dikombinasi dengan obat antihipertensi lain seperti golongan beta blocker ${ }^{30}$.

\section{Kesesuaian Pemberian Obat Antihipertensi}

Data yang diperoleh kemudian dilakukan analisis kesesuaian pemberian obat antihipertensi berdasarkan kesesuaian pemilihan obat dan dosis dengan mengacu pada JNC 8. Berdasarkan hasil penelitian dari 72 data rekam medis diperoleh kesesuaian pemilihan obat antihipertensi pada pasien lansia di Puskesmas Sukarami Palembang sebanyak $100 \%$, dimana hasil penelitian ini dilihat berdasarkan diagnosis dari pasien dan obat yang diresepkan kepada pasien dan dibandingkan dengan pedoman atau literatur yang digunakan yaitu JNC 8. Hasil penelitian ini sama dengan hasil penelitian di Unit Pelaksana Teknis Dinas (UPTD) Puskesmas Airmadidi, yaitu pasien hipertensi mendapatkan tepat obat sesuai dengan pedoman JNC $8^{28}$.

Menurut JNC 8, algoritma pengobatan pasien hipertensi umur $\geq 60$ tahun dengan atau tidak adanya penyakit penyerta diabetes dimulai dengan diuretik thiazid atau ACEl atau Angiotensin II Receptor Blokers (ARB) atau CCB, dalam bentuk tunggal atau dalam kombinasi sebagai lini pertama dan $\beta$-blocker atau antagonis aldosteron 
atau alfa blocker atau penghambat renin langsung sebagai lini kedua ${ }^{17}$. Pasien lansia yang melakukan pengobatan di Puskesmas Sukarami Palembang mendapatkan pengobatan yang sesuai dengan pedoman JNC 8 yaitu 68 pasien $(94,44 \%)$ mendapatkan pengobatan monoterapi dan 4 pasien (5,56\%) mendapatkan pengobatan kombinasi dua obat.

Pengobatan monoterapi yang didapatkan pasien golongan $\mathrm{CCB}$ yaitu amlodipin dimana 25 pasien mengalami hipertensi stage I dan 43 pasien mengalami hipertensi stage II. Pengobatan hipertensi untuk stage I dan stage II sama, yaitu boleh menggunakan tunggal ataupun kombinasi tergantung dari kondisi pasien tersebut dan faktor risiko lainnya seperti usia, penyakit penyerta, dosis obat, dan mekanisme kerja obat ${ }^{17}$.

Terapi kombinasi dapat menurunkan tekanan darah lebih besar dengan efek samping yang minimal, terutama jika dibandingkan dengan penggunaan monoterapi antihipertensi dengan dosis yang tinggi. Untuk pemberian politerapi kombinasi dua obat pada penelitian ini diberikan pengobatan golongan CCB dan ACEI serta CCB dan beta blocker. Pemberian obat kombinasi ini sudah sesuai dengan pedoman JNC 8 yaitu direkomendasikan pemberian politerapi kombinasi dua obat golongan ACEI atau ARB dengan CCB lebih banyak diberikan pada pasien hipertensi karena bisa ditoleransi dengan baik pada awal pengobatan dan lebih unggul dari kombinasi dengan diuretik dalam menghambat stimulasi Renin Angiotensin Aldosterone System (RAAS) ${ }^{17,28,29}$. Kombinasi obat golongan CCB dihidropiridin (amlodipine) dan Beta blocker (bisoprolol) digunakan sebagai tambahan untuk pengaturan denyut jantung, dapat menyebabkan penurunan tekanan darah yang lebih baik dibanding monoterapi masing-masing obat tersebut ${ }^{30}$.

Berdasarkan hasil Tabel 8 dari 72 data rekam medis, terdapat 69 data rekam medis yang menunjukan dosis sesuai $(95,83 \%)$, dan terdapat 3 data rekam medis yang dosis terlalu tinggi (4,17\%). Hal ini disebabkan karena dosis yang diberikan atau diresepkan kepada pasien melebihi dosis maksimum yang telah ditetapkan dalam algoritma terapi menurut JNC 8. Bila peresepan obat antihipertensi berada pada rentang dosis minimal dan dosis perhari yang dianjurkan maka peresepan dikatakan dosis nya sesuai. Dikatakan dosis kurang atau dosis terlalu rendah apabila dosis yang 
diterima pasien berada dibawah rentang dosis terapi yang seharusnya diterima pasien, dosis yang terlalu rendah dapat menyebabkan kadar obat dalam darah berada dibawah kisaran terapi sehingga tidak dapat memberikan respon yang diharapkan yaitu penurunan tekanan darah tidak tercapai. Sebaliknya dosis obat yang terlalu tinggi dapat menyebabkan kadar obat dalam darah melebihi kisaran terapi menyebabkan keadaan munculnya efek samping utama antihipertensi yaitu hipotensi dan kemungkinan efek toksisitas lainnya ${ }^{18}$.

Tabel VIII. Kesesuaian Pemilihan Dosis Antihipertensi yang Diberikan Pada Pasien Lansia di Puskesmas Sukarami Palembang

\begin{tabular}{cccccc}
\hline & & \multicolumn{4}{c}{ Kesesuaian Obat } \\
\cline { 3 - 6 } $\begin{array}{c}\text { Terapi yang } \\
\text { diberikan }\end{array}$ & Pedoman JNC 8 & \multicolumn{3}{c}{ Sesuai } & \multicolumn{2}{c}{ Tidak Sesuai } \\
\cline { 3 - 6 } & $\begin{array}{c}\text { Frekuensi } \\
\text { (n) }\end{array}$ & $\begin{array}{c}\text { Persentase } \\
\text { (\%) }\end{array}$ & $\begin{array}{c}\text { Frekuensi } \\
\text { (n) }\end{array}$ & $\begin{array}{c}\text { Persentase } \\
\text { (\%) }\end{array}$ \\
\hline $\begin{array}{c}\text { Amlodipin } \\
5-30 \mathrm{mg} / \text { hari } \\
\text { Captopril }\end{array}$ & $\begin{array}{c}\text { Amlodipin } \\
2,5-10 \mathrm{mg} / \text { hari } \\
\text { Captoptil }\end{array}$ & 66 & 91,67 & 2 & 2,78 \\
$25-75 \mathrm{mg} /$ hari \\
$\begin{array}{c}\text { Bisoprolol } \\
25-50 \mathrm{mg} / \text { hari }\end{array}$ & 2 & 2,78 & 1 & 1,39 \\
$\begin{array}{c}\text { Bisoprolol } \\
\text { 2,5-5mg/hari } \\
\text { Total }\end{array}$ & $2,5-10 \mathrm{mg} /$ hari & 1 & 1,39 & - & - \\
\hline
\end{tabular}

Berdasarkan JNC 8 dosis maksimum amlodipin yaitu 2,5-10 mg/hari, di dalam data penelitian yang didapatkan terdapat dua pasien yang mendapatkan dosis amlodipin melebihi dosis maksimum yaitu pasien yang mendapatkan amlodipin dengan dosis $2 \times 10 \mathrm{mg}$ dan pasien yang mendapatkan amlodipin dengan dosis $3 \times 10$ $\mathrm{mg}$. Pada pasien yang mendapatkan dosis $30 \mathrm{mg} / \mathrm{hari}$ merupakan pasien dengan penyakit penyerta diabetes mellitus yang memiliki tekanan darah tidak terkontrol, akan tetapi dosis yang tidak sesuai dengan pedoman JNC 8 dan pada saat pemeriksaan tekanan darah sudah mencapai target yaitu 130/85 mmHg. Pemberian dosis berlebih bisa menyebabkan munculnya efek samping dari obat tersebut, amlodipin adalah salah satu golongan obat CCB dihidropiridin, apabila diberikan dosis yang berlebihan dapat menimbulkan aktivasi reflek simpatis disertai takikardia ringan yang akan mempertahankan atau meningkatkan curah jantung pada sebagian besar pasien dan dapat berpotensi menimbulkan kecenderungan peningkatan tekanan darah ${ }^{31}$. 
Menurut pedoman JNC 8 dosis maksimum captopril yaitu $25-50 \mathrm{mg} / \mathrm{hari}$, didalam data penelitian didapatkan satu pasien yang menerima dosis captopril melebihi dosis maksimum perhari yaitu $3 \times 25 \mathrm{mg}$. Jika sesuai pedoman JNC 8 pasien ini dikatakakan menerima dosis yang tidak sesuai karena terlalu tinggi melebihi batas maksimum. Penggunaan kaptopril dengan dosis tinggi dapat mengakibatkan hilangnya rasa, neutropenia, proteinuria, lesi oral, dan scalded mouth syndrome ${ }^{32}$. Pemberian dosis yang melebihi dosis maksimum perhari dapat terjadi jika dokter melihat pertimbangan lainnya sesuai kondisi pasien atau melihat dari pedoman pengobatan lain.

\section{KESIMPULAN DAN SARAN}

Berdasarkan hasil penelitian dan pembahasan mengenai Evaluasi Pemberian dan Penggunaan Obat Antihipertensi pada Pasien Lansia di Puskesmas Sukarami Palembang didapatkan hasil bahwa sebagian besar pasien dalam penelitian ini, berjenis kelamin lakilaki $(54,17 \%)$, usia kisaran 60-74 tahun (91,67\%), dengan terbanyak hipertensi stage II $(65,28 \%)$, serta penyakit penyerta terbanyak yaitu diabetes mellitus $(15,28 \%)$. Golongan obat antihipertensi terbanyak yaitu CCB dengan obat terbanyak amlodipin $(94,44 \%)$. Pola terapi paling banyak yaitu monoterapi golongan CCB amlodipin $(94,44 \%)$, penggunaan politerapi dua obat dengan kombinasi terbanyak yaitu golongan CCB dan ACEI (4,17\%). Kesesuaian pemilihan obat antihipertensi sesuai dengan pedoman JNC 8 (100\%) dan kesesuaian pemilihan dosis obat antihipertensi dengan pedoman JNC 8 sebanyak 69 pasien $(95,83 \%)$ dan dosis terlalu tinggi sebanyak 3 pasien $(4,17 \%)$.

Perlu analsisi lebih lanjut mengenai ketidak sesuaian dosis pasien untuk mencegah terjadinya reaksi obat yang tidak diinginkan.

\section{KONFLIK KEPENTINGAN}

Seluruh penulis menyatakan tidak terdapat potensi konflik kepentingan dengan penelitian dan atau publikasi artikel ini. 


\section{DAFTAR PUSTAKA}

1. Brunner., Suddarth., 2016. Keperawatan Medikal Bedah. EGC. Jakarta.

2. Departemen Kesehatan RI. 2018. Profil Kesehatan Tahun 2018. Dinas Kesehatan Kota Palembang. Palembang.

3. Dinas Kesehatan Provinsi Sumatera Selatan. 2019. Profil Kesehatan Provinsi Sumatera Selatan tahun 2019. Pusat data dan Informasi Kesehatan. Palembang.

4. Pharmaceutical Care Network Europe Foundation (PCNE). 2017. Clasification for Drug Related Problems. V8.02. Zuidlaren.

5. Andriyana, N.D., 2018. Evaluasi Terapi Penggunaan Obat Antihipertensi pada Pasien Geriatri di Instalasi Rawat Inap RSUD Dr. Moewardi di Surakarta tahun 2016. Universitas Muhammadiyah Surakarta. Surakarta.

6. Lestari, I.G., Isnaini, N., 2018. Pengaruh Self Management terhadap Tekanan Darah Lansia yang Mengalami Hipertensi. Indonesian Journal For Health Sciences;02(1):7-18.

7. Sugiyono. 2018. Metode Penelitian Kuantitatif Kualitatif dan R\&D. Alfabeta. Jakarta.

8. Kementerian Kesehatan RI. 2013. Pedoman Teknis Penemuan dan Tatalaksana Hipertensi. Direktorat Pengendalian Penyakit Tidak Menular Subdit Pengendalian Penyakit Jantung dan Pembuluh Darah. Jakarta.

9. Amanda, D., Martini, S., 2018. Hubungan Karakteristik dan Obesitas Sentral dengan Kejadian Hipertensi. Jurnal Berkala Epidemiologi;6(1):43-50.

10. Tirtasari, S., Kodim, N., 2019. Prevalensi dan Karakteristik Hipertensi Pada Usia Dewasa Muda di Indonesia. Tarumanagara Medical Journal;1(2):395-402.

11. Silaen, J.B., 2018. Kejadian Hipertensi Pada Masyarakat di Wilayah Kerja Puskesmas Harapan Raya Pekanbaru. Jurnal IPTEKS Terapan;12(1):64-77.

12. Badan Penelitian dan Pengembangan Kesehatan Kementerian Republik Indonesia., 2018., Riset Kesehatan Dasar (RISKESDAS). Balitbang Kemenkes RI. Jakarta

13. Purwono, J., Sari, R., Ratnasari, A., Budianto, A., 2020. Pola Konsumsi Garam dengan Kejadian Hipertensi pada Lansia. Jurnal Wacana Kesehatan;5(1):531-542.

14. Rahman, A., 2019. Evaluasi Ketepatan Pemilihan Obat Hipertensi Pada Pasien Lansia Di Puskesmas Kota Gede II Dareah Istimewa Yogyakarta Periode Oktober 2017-Januari 2018. Universitas Ahmad Dahlan. Yogyakarta.

15. Kholifah, S.N., 2016. Modul Bahan Ajar Cetak Keperawatan: Keperawatan Gerontik. Kementerian Kesehatan Republik Indonesia. Jakarta.

16. Badan Pusat Statistik Indonesia. 2020. Angka Harapan Hidup (AHH) menurut Provinsi dan Jenis Kelamin Tahun) 2018-2020. Badan Pusat Statistik Indonesia. Jakarta.

17. James, A., Oparil, S., dan Carter, L., 2013. 2014 Evidence-Based Guidelines for the Management of High Blood Pressure in Adults: Report From the Panel Members Appointed to the Eight Joint National Committee (JNC 8). American Medical Association : JAMA

18. Untari, E.K., Agilina, A.R., Sussanti, R., 2018. Evaluasi Rasionalitas Penggunaan Obat Antihipertensi di Puskesmas Siantan Hilir Kota Pontianak tahun 2015. Pharmaceutical Sciences and Research;5(1):32-39.

19. Yuriah, A., Astuti, AT., Inayah., 2019. Hubungan Asupan Lemak, Serat dan Rasio Lingkar Pinggang Pinggul dengan Tekanan Darah Pasien Hipertensi di Puskesmas Gondokusuman I Yogyakarta. IImu Gizi Indonesia;2(2):115-124. 
20. Sihombing, M., 2017. Faktor yang Berhubungan dengan Hipertensi pada Penduduk Indonesia yang Menderita Diabetes Melitus (Data Riskesdas 2013). Puslitbang Sumber Daya dan Pelayanan Kesehatan. Jakarta.

21. Ndruru, R.K., Sitorus, S., Barus, N., 2019, Gambaran Diagnostik dan Penatalaksanaan Gastritis Rawat Inap BPJS di RSU Royal Prima Medan Tahun 2017. Fakultas Kedokteran. Jurnal Kedokteran dan Kesehatan;15(2):209-216.

22. Seke, P.A., Bidjuni, H.J., Lolong, J., 2016. Hubungan Kejadian Stres Dengan Penyakit Hipertensi Pada Lansia Di Balai Penyantunan Lanjut Usia Senjah Cerah Kecamatan Mapanget Kota Manado. Jurnal Keperawatan;4(2):1-5.

23. Aritonang, M., 2021. Pengaruh Stress Dan Pola Makan Dengan Frekuensi Kekambuhan Penyakit Pada Penderita Gastritis Di RSUD Dr. Pirngadi Medan Tahun 2020. Jurnal Pandu Husada;2(2):84-91.

24. Antara, G.A.M.W.D., 2019. Evaluasi Rasionalitas Penggunaan Obat Antihipertensi Pada Pasien Hipertensi Di Puskesmas Pasir Panjang Periode Januari - Maret 2018. Universitas Citra Bangsa. Kupang.

25. Tambuwun, P.G., Suling, P.L., Mintjelungan, C.N., 2015. Gambaran Keluhan Di Rongga Mulut Pada Pengguna Obat Antihipertensi Di Poliklinik Penyakit Dalam Rumah Sakit Tingkat III Robert Wolter Monginsidi Manado. Jurnal e-Gigi;3(2):241-245.

26. Nilansari, A.F., Yasin, N.M., Puspandari D.A., 2020. Gambaran Pola Penggunaan Obat Antihipertensi Pada Pasien Rawat Inap di RSUD Panembahan Senopati. LUMBUNG FARMASI: Jurnal Ilmu Kefarmasian; 1(2):73-79.

27. Perhimpunan Dokter Spesialis Kardiovaskular Indonesia. 2015. Pedoman Tatalaksana Hipertensi pada Penyakit Kardiovaskular. Perhimpunan Dokter Spesialis Kardiovaskular Indonesia. Jakarta.

28. Polopadang, Y., Mongie, J., Maarisit, W., Karauwan, F., 2021. Pola Peresepan Penggunaan Obat Di UPTD Puskesmas Airmadidi. Jurnal Biofarmasetikal Tropis;4(1):97-101.

29. Putri, L.S.A., Satriyasa, B.K., Jawi, I.,M., 2019. Gambaran Pola Penggunaan Obat Antihipertensi Pada Pasien Di Instalasi Rawat Inap RSUP Sanglah Denpasar Tahun 2016. Jurnal Medika Udayana;8(6).

30. Richards, T.R., Tobe, S.W., 2014. Combining Other Antihypertensive Drugs With $\beta$ blockers in Hypertension: A Focus On Safety And Tolerability. Canadian Journal of Cardiology;30(5):42-46.

31. Katzung, B.T. 2018. Basic \& Clinical Pharmacology (Fourteenth Edition). McGraw-Hill. United State.

32. Halim, M.C., Andrajati, R., Supardi, S., 2015. Resiko Penggunaan ACEi terhadap Kejadian Batuk Kering pada Pasien Hipertensi di RSUD Cengkareng dan RSUD Tarakan DKI Jakarta. Jurnal Kefarmasian Indonesia;5(2):113-122. 